\title{
Property of all plastic photo-rechargeable battery
}

\section{オールプラスチック光蓄電池の物性}

\author{
Takahiro KUBOTA and Sadao UEGUSA \\ Department of Electrical Engineering, Tokai University, 1117 Kitakaname, \\ Hiratsuka, Kanagawa, 259-1292 JAPAN \\ TEL:81-0463-58-1211 (EXT. 4162)
}

( Received 14, November 1998 Accepted 12, June 1999 )

In this paper, construction of photo-catatytic rechargeable battery was studied, using organic materials. More suitable battery characteristic was obtained when the resistance of the electrode was decreased by decreasing amount of doping in the electrode. The effect of pigment in electrodes was also investigated.

Keywords: all plastic device, photo-rechargeable battery

\section{I . INTRODUCTION}

光蓄電池のアイデアは1980年代トリピッッ氏らにより䉓気 変換と蓄琽がーつの素子内で連続したプロセスとして現実可 能と発表されたものである。'日本では、鹿児島大学野見山氏 により、光触媒としてT i O 多面的に検討されている。'本研究では、光触媒として䇣外城 に光吸収分布の中心を有する傾向がある無權物質の代方りに、 可視光域にも光吸收分布をもつ有機色素を用いた。また、蓄 龟材料としてポリピロールを使用した。したがって、両者か らなるデバイスとして全てを有機物で檕成させた事になる。 こえにより、有機物は無機物に比べ低コストで柔軟性のある 素子作成が可能であり、このことも大きな利点として挙げら れる。:このオールプラスチック光蓄琽池を用い、膜を構成し ている染リピロールや色素などの割合や量を変化させたとき の膜内部の構造による基本特性を検討した。

\section{EXPERIMENTAL}

本実歌は脱ドーピング法による特性、色素ありの重合量の 変化による特性、色素の密度変化による特性の3つの視点か ら測定を行った。膜の電解重合には、50 c cのビーカーに アセトニトリル、ポリピロール、無水ホウフッ化リチウム、 オキソノール色素を所定の量入え、十分挸搔した。その後真 空引きを行い、これを溶液とした。三電䨗はネサガラスで対

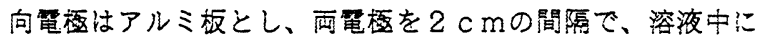
$4 \mathrm{~cm}^{2}$ 掩入した。これにクーロンメーター、䉓源をFig. 1 の ように眼線した。脱ドーピング法による特性については、印 加䉓生 $5[\mathrm{~V}]$ で $2[\mathrm{c}]$ 重合させた。その後、極性を逆に し、所定の量の脱ドーピングを所定の量行った。次に色素あ りの重合量の変化による特性については、ビーカーを2つ用 意し、1つのビーカーには色素ありを、もう一方のビーカー には色素なしを䉓解溶液とした。そしてまず色素なしを用い
所定の量重合した。次に色素ありを用い所定の量重合した。 次に色素の密度変化による特性については、脱ドーピング法 による特性と同じ重合条件で色素の量だけ所定の量にし重合 した。作蹩した膜に光源としてレフレックスランプを用い、 試料面で光出力 $40 \mathrm{~mW}$ 設定して、光照射を 1 分間行い、 その後に 1 分間光照射を停止した。このサイクルを 10 分間 にわたって行い、蓄笪䉓壬を測定した。

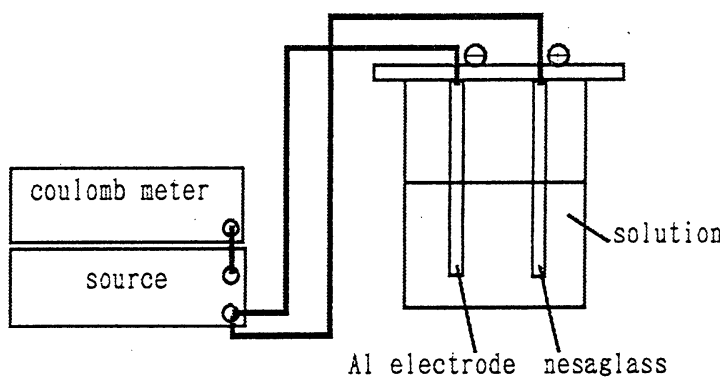

FiG. 1. Firing diagram of experiment at apparatus

\section{RESULTS AND DISCUSSION}

Figure 2 浪脱ドーピング量の変化による平均蓄䉓䉓生を示 し、Fig. 3 注帨ドーピング量の变化による平汮㪟電䉓圧特性 の結果である。この平均蓄電督王は、光嬖射をした5分間の 蓄䉓䉓压量の平均であり、平均放䉓䉓压注、光照射をしてい ない5分間の故䉓電圧量の平均である。Figure 2 より、脱ド ーピング量を堌加させていくと平均蓄電電压法減少する傾向 を生じた。Figure 3より、脱ドーピング量を堌加させていく と平均故晸耗纴は增加する傎向を生じた。この原因として脱 ドーピング法は膜内部の不純物負イオンを除去し、膜の内部 抵氿を增加させるものである。しかし膜の罜妘率が変化する 
だけでなく、負イオン化している色素自体む流出することが 考えられる。Figure 2、3の結策を見る限りでは、莫の抵抗 率を增加させ、放䉓量を減少させていくという考えはせずに、 反対に等䉓性を增加するほうが膜の性能、つまり蕃䉓量を增 加し故䉓量を娍少させると考えられる。

Figure 4 は色素ありの重合县の变化よる平均蓄龟䉓生特性 の結果である。Figure 4 の結果としては、色票ありのピロー ル膜の重合量の割合が大きい方の平均蓄䉓䉓压は増加する傾 向がある。これは光能媒である色絜が入っている膜の重合量 の多い方が、光䉓子の励起される量も多いと考えられ、それ だけ蕃䉓される軍子も多くなっていると考えられる。

Figure 5 は色案の密度变化による平均著龟龟王符性の結果 である。Figure 5の結果として表れているのは、色素の密度

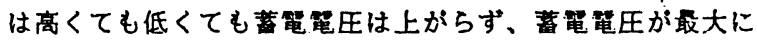
なる最通值があるということが認められた。まず色密度 が高い場合を考えると、膜の内部で光能禁である色案が多い ので、光的起される䉓子の量泣いと考えられる。しかし、 色絜の密度が高い分蓄䉓材料の密度が低くなり、そのため、 蓄えられる奄荷の貴が限られてしまうからと考えられる。こ のため䭂和状態になり、それ以上になった䉓荷は逃げている のではないと考えられる。次に色案の密度が低い分を考え ると、膜の内部で光触媒である色素が少ないので、当然光恸 起される䉓子の畠も少ないと考えられる。そのため蓄えられ 万䉓荷か減少するのではないかと考えられる。

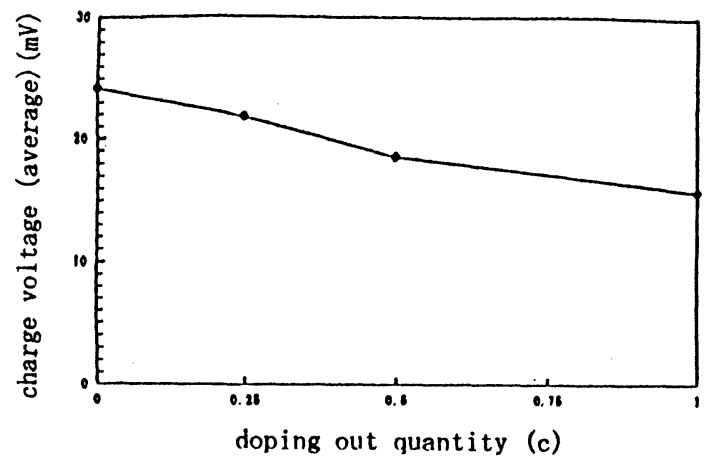

FIG. 2. Doping out quantity - averaged charge vol tage

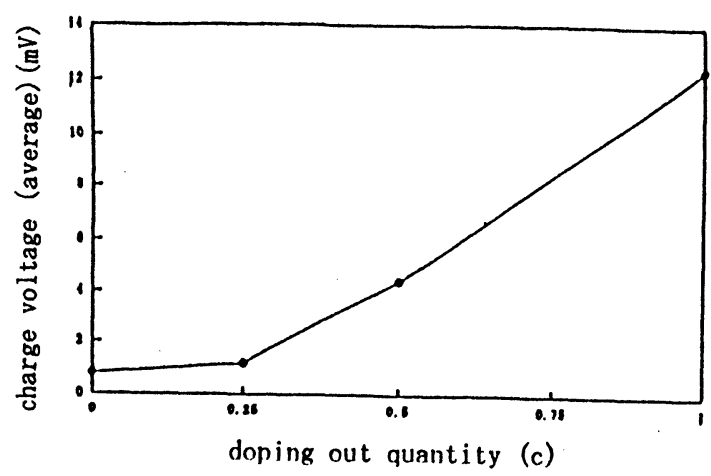

FIG. 3 . Doping out quantity - averaged discharge vol tage
IV. CONCLLSION

1）脱ドーピング法による特性については、脱ドーピング 甚を增加させると、蓄奄量は減少し、放龟是は增加した。 よって膜の性能は下がる。これは脱ドーピングは膜の抵 抗率を上界させるからである。よって逆に膜の抵抗率を 減少させてやれば良い。

2) 膜の重ね方による符性については、膜全体に対し、色

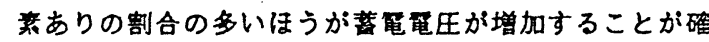

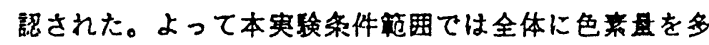
くを重合したほうが良い。

3）色案の密度变化による特性については、色案の密度と

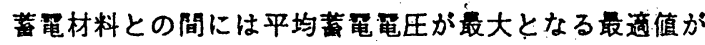
ある事を確認した。この最通值が、本央䟻条件筑用では 色萦の密度が約5.71 [10-5*mg/m1] の所であったといえる。 この最缡値を利用し、重合させることが重要である。

\section{REFERENCE}

1 Y.Simizu. Trial manufacture and property of all plastic photo-rechargeble battery, electric academic meeting national convention. Y. Simizu (1997) $\mathrm{pl}$

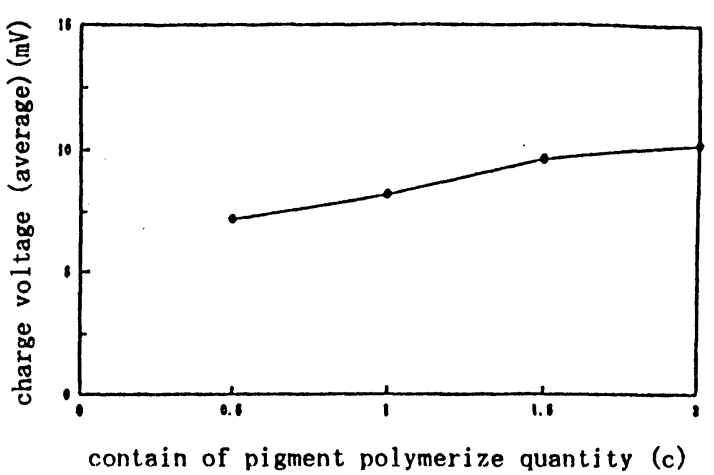

FIG. 4 Contain of pigment polymerize quantity averaged charge voltage

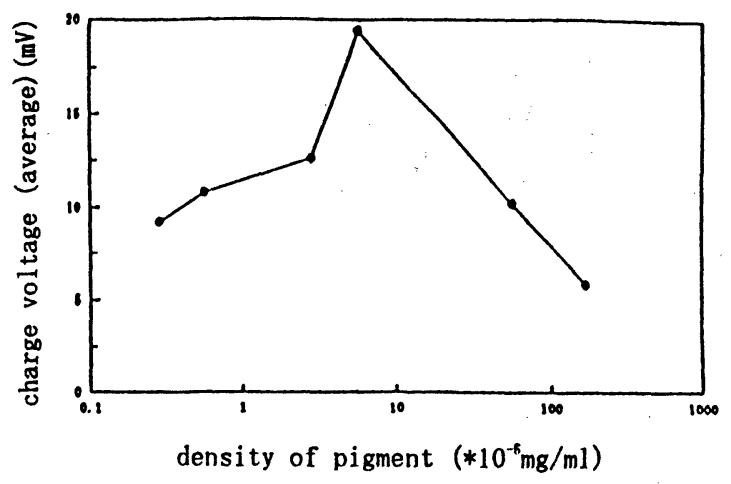

FIG. 5 . Density of pigment - averaged discharge vol tage

Presented at '98 SAS Intelligent Symposium 